\title{
The Effect of a Shortened Dry Period on Intramammary Infections During the Subsequent Lactation ${ }^{1}$
}

\author{
G. T. Church, ${ }^{*}$ L. K. Fox, $\dagger^{2}$ C. T. Gaskins, ${ }^{*}$ D. D. Hancock, $\dagger$ and J. M. Gay $\dagger$ \\ ${ }^{*}$ Department of Animal Sciences, and \\ †Veterinary Clinical Sciences, Washington State University, Pullman 99164
}

\begin{abstract}
Several recent studies have investigated the effect of shortened dry periods on milk production in the subsequent lactation. What is lacking from these studies is an understanding of the effect that a shortened dry period has on udder health. Four herds, 156 cows, were studied to determine if a shortened dry period (30 d) had a negative effect on mammary gland health during the subsequent lactation as opposed to cows assigned to a long, 45 or $60 \mathrm{~d}$, dry period. Cows in 2 herds were assigned to either 30- or 60-d dry periods (group I), whereas cows in the other 2 herds were assigned to either 30- or 45-d dry periods (group II). Intramammary instillation of commercial preparations of cephapirin benzathine, $300 \mathrm{mg}$ (dry cow formulation), was given to cows assigned a 45- or 60-d dry period length protocol, and $200 \mathrm{mg}$ (lactating cow formulation) was administered to cows assigned a 30-d dry period. Differences in response variables to dry period length were compared within group. Cure rates for 60- vs. 30-d dry period cows were $72 \%(28 / 39)$ vs. $81 \%(30 / 37)$ and $74 \%(25 / 34)$ and $73 \%$ (27/37) for 45- vs. 30-d dry periods. Differences were not statistically significant for either comparison group. The majority of intramammary infections were caused by the minor pathogens, coagulase-negative staphylococci $(\mathrm{n}=102)$ or Corynebacterium bovis ( $\mathrm{n}$ =11). Only 11 cows had intramammary infections by major pathogens. The herd average percentage of new intramammary infections ranged from 6 to $9 \%$ and did not differ among herds between treatment groups. Linear somatic cell counts were not significantly affected by dry period length during the first 6 to $7 \mathrm{mo}$ of the subsequent lactation. Milk production did differ between groups. Mature equivalent milk production was greater in group I cows given a 60 -d dry period (11,942 $\pm 2,059 \mathrm{~kg}$ ) as opposed to those given a 30 -d dry period
\end{abstract}

Received May 20, 2008.

Accepted July 21, 2008.

${ }^{1}$ This project was supported in part by ARC project 07090858 .

${ }^{2}$ Corresponding author: Fox@wsu.edu
$(10,749 \pm 2,321 \mathrm{~kg})$. Cows given a 45 -d dry period did not produce more milk than cows with a 30-d dry period in group II. Although shortening the dry period to $30 \mathrm{~d}$ did not have untoward effects on mammary gland health as measured by intramammary infections or milk somatic cell counts, production may be adversely affected when dry periods are shortened to $30 \mathrm{~d}$.

Key words: mastitis, dry period length, intramammary therapy, linear somatic cell count

\section{INTRODUCTION}

The nonlactating period of the dairy cow is commonly referred to as the dry period. During this period, the mammary gland undergoes dramatic changes in histology and physiology, characterized as involution, which is believed to be necessary for maximal milk production in the subsequent lactation (Hurley, 1989). Yet, the recommendation on the length of the dry period has been debated for centuries. Dix Arnold and Becker (1936) refer to an 1805 text in which the range in advocated dry period lengths was from $10 \mathrm{~d}$ to 2 mo. These authors also refer to 10 widely used dairy management texts published between 1911 and 1930 in which the recommended dry period length ranged from 4 to 10 wk. Dix Arnold and Becker (1936) reviewed 3 studies recent to their time in which dairy cattle production records were analyzed retrospectively, and they report that the minimum dry period to achieve maximum yield in the subsequent lactation was 30 to $39 \mathrm{~d}$ and that a 2 -mo period seemed most favorable. Bachman and Schairer (2003) summarized 18 studies conducted between 1936 and 1996 that concluded that the best production in the subsequent lactation can be generally achieved when cows have a dry period length of 40 to $60 \mathrm{~d}$. Bachman and Schairer (2003) also referenced 3 studies conducted since 2000 that suggested a dry period of less than $40 \mathrm{~d}$ may be most profitable. Bachman and Schairer (2003) argue that the production gained from the longer lactation that precedes the shorter dry period (30 d) may more than compensate for small and maybe insignificantly decreased yields in the lactation that follows the short dry periods. 
Since the review (Bachman and Schairer, 2003), there have been several studies examining the effect of length of the dry period on milk production (Gulay et al., 2003; Annen et al., 2004; Rastani et al., 2005; Kuhn et al., 2006a, 2007; Pezeshki et al., 2007). Some indicate that there is a difference between parity responses to short dry periods with those first-parity cows suffering lost production (Annen et al., 2004; Kuhn et al., 2006a; Pezeshki et al., 2007). Although some of these more recent studies indicate production yield was best with longer dry periods (Kuhn et al., 2006a, 2007), others indicated that shorter dry periods of approximately 30 $\mathrm{d}$ did not result in a significant decrease in subsequent lactation yield (Gulay et al., 2003; Annen et al., 2004; Pezeshki et al., 2007). Rastani et al. (2005) indicated that total fluid yield was greatest with cows with 60vs. 30-d dry periods; however, when yields were corrected for total solids, there was no significant effect of dry period length.

The dry period is a time when cows receive intramammary antibiotic therapy as part of the recommended mastitis control program (Dodd et al., 1969). Intramammary antibiotic dry cow products are generally formulated for dry periods longer than $30 \mathrm{~d}$. Many cows enrolled in 30-d dry periods will calve earlier than expected as indicated by Gulay et al. (2005), which could increase the risk of antibiotic residues contaminating the raw milk supply. We hypothesized that standard commercial antibiotic therapy administered to cows assigned a long dry period (45 or $60 \mathrm{~d}$ ) would result in improved udder health postpartum as compared with those assigned a 30-d dry period and given a similar therapy product, but designed for lactating cows. The basis for this hypothesis was the expected dry period IMI cure rates of $75 \%$ (Erskine et al., 2003) compared with the expected cure rate of less than $25 \%$ (Timms and Schultz 1984) for a lactating cow therapy product administered to cure subclinical IMI during an established lactation.

\section{MATERIALS AND METHODS}

Four herds, members of the DHIA using the supervised production testing program at approximately monthly intervals, were enrolled in the study. Cows studied $(n=156)$ were systematically assigned long or short dry periods by identification numbers. In 3 of the 4 herds, odd-numbered cows were assigned to the long dry period (45 and $60 \mathrm{~d}$, positive control), and evennumbered cows were assigned to the short dry period $(30 \mathrm{~d})$. Cows in the fourth herd with even-numbered ear tags were assigned to the long dry period (45 d), whereas cows with odd ear tag numbers were assigned to the short dry period. Herd managers did not want to deviate from their standard dry period length routine for cows enrolled in long dry periods. Thus, cows from 1 commercial herd and the Washington State University herd had either 60- or 30-d dry periods and comprised group I. Cows from a second commercial herd and the University of Idaho herd had either 45- or 30-d dry periods and were group II. There were 46 primiparae and 52 multiparae in group I and 37 primiparae and 21 multiparae in group II.

At dry-off, duplicate mammary quarter foremilk samples were aseptically collected from each cow. Teat ends were wiped with towels soaked in 70\% isopropyl alcohol before the last milking of the lactation. The first stream of milk was discarded, and then milk was collected into sterile disposable test tubes. Teat ends were wiped for the second time before the second set of samples was collected and stored at $-5^{\circ} \mathrm{C}$ until cultured. Storage of samples rarely exceeded $2 \mathrm{wk}$ as bimonthly visits were made to each dairy. After cows were milked, the teat ends were wiped for the final time before intramammary infusion. Using the partial insertion method, cows assigned to 60- and 45-d (long) dry periods received an intramammary infusion of cephapirin benzathine, $300 \mathrm{mg}$ (Cefa-Dri, Fort Dodge Animal Health, Fort Dodge, IA), and cows assigned a 30-d (short) dry period received an intramammary infusion of cephapirin sodium, $200 \mathrm{mg}$ (Cefa-Lak, Fort Dodge Animal Health).

At calving, single mammary quarter foremilk samples were aseptically collected at freshening ( 0 to $3 \mathrm{~d}$ postpartum) and at $7( \pm 3), 14( \pm 3)$, and $21( \pm 3) \mathrm{d}$ postpartum. Samples were stored at $-5^{\circ} \mathrm{C}$ until cultured. An edema scoring system described by Nestor et al. (1988) was used to monitor the edema of all cattle at freshening. The rating system was as follows: $1=$ no visual or palpable edema; 2 = slight edema, edema around the base of the udder and teats; $3=$ moderate edema, the lower half of the udder was edematous; 4 $=$ severe edema, swelling was observed on almost the entire udder; and $5=$ very severe edema, the cow was edematous through the hind thighs, the brisket, or both. Personnel at each dairy farm were responsible for edema scoring at parturition, when the first milk sample was collected. Study personnel were responsible for training dairy personnel on the methods used to collect milk samples and to score udders for edema.

Milk samples were thawed at ambient temperature before culture. Samples were mixed vigorously, and a 50- $\mu \mathrm{L}$ aliquot from each sample was spread on blood agar. All plates were incubated at $37^{\circ} \mathrm{C}$ for $48 \mathrm{~h}$ and examined at 24-h intervals. Organisms were presumptively identified using National Mastitis Council laboratory procedures (Hogan et al., 1999) as coagulasepositive staphylococci, CNS, Corynebacterium spp., 
Bacilli, Streptococcus spp., and coliforms. Organisms were differentiated using catalase reaction, coagulase test, reaction on Christie-Atkins-Munch-Peterson esculin agar, MacConkey agar, and Gram stain. All milk samples collected at freshening were screened for antibiotic residues (Delvotest P MINI, DSM Food Specialties, Menomonee Falls, WI). Cows that were found positive for residues at freshening were screened again using the 7-d postpartum sample and thereafter until screening results were negative.

Intramammary infections from dry-off mammary quarter milk samples were diagnosed based on isolation of the same mastitis pathogens in both samples. Samples that consisted of 3 or more morphologically dissimilar colony types were considered contaminated. A mammary quarter was diagnosed as cured if: 1) at least 3 of 4 postpartum samples were cultured, 2) the fresh sample was not missed, and 3) the same pathogen isolated at dry-off was not cultured in any postpartum sample. Contrarily, a mammary quarter that did not test positive for a pathogen at dry-off, but from which the same pathogen could be isolated from 2 of 3 consecutive postpartum samples, was diagnosed as a new infection.

Minimum sample size was determined using PROC POWER 2 sample frequency test for $x^{2}$. Estimated group proportions of 0.23 for $30 \mathrm{~d}$ cure rates and 0.75 for $60 \mathrm{~d}$ cure rates were based on expected cures of subclinical mastitis using lactation therapy (Timms and Schultz, 1984) and expected cures using dry cow therapy (Erskine et al., 2003). The power of the test was set at $0.95, \alpha=0.05$, and 21 cows were found to be required per group. Differences in cured quarters or prevention of new infections between group I or group II dry periods for major, minor, or other pathogens were compared using the Mantel-Haenszel $X^{2}$ test (PROC FREQ), which accounts for differences between herds, and confirmed with a categorical model (PROC CATMOD) accounting for cow effects. The categorical model was set with cure as the dependent variable and herd, treatment, and cow within herd and treatment as the dependent variables. Mature equivalent 305-d lactations, linear milk SCC (LSCC), and edema scores were analyzed in a completely randomized design with a model that included length of dry period (protocol), herd, and protocol $\times$ herd interaction as fixed effects (PROC GLM). All analyses were conducted using SAS (version 9.1, SAS Institute, Cary, NC).

\section{RESULTS}

The average dry period length for cows enrolled in the short dry period was $33.9 \mathrm{~d}( \pm 13.4 \mathrm{~d})$, ranging from 14 to $93 \mathrm{~d}$ dry. The long dry periods of 2 theoretical lengths ( 45 or $60 \mathrm{~d}$ ) averaged $45.6 \mathrm{~d} \pm 4.9 \mathrm{~d}$ and $63.1 \mathrm{~d}$ $\pm 14.6 \mathrm{~d}$, with respective ranges of 32 to 56 and 15 to $140 \mathrm{~d}$ dry.

Intramammary instillation of cephapirin benzathine dry cow product, for cows assigned a 45- or 60-d dry period, or cephapirin sodium lactating cow product, for cows assigned a 30- $d$ dry period, did not have a significant effect on the percentages of cures (Tables 1 and 2). Overall, $72 \%$ [confidence interval $(\mathbf{C I})=0.57$ to 0.86 ] of infected cows assigned a 60-d dry period were cured as compared with $81 \%(\mathrm{CI}=0.68$ to 0.94$)$ for cows assigned a $30-d$ dry period in group I. Percentages of cures were $74(\mathrm{CI}=0.59$ to 0.89$)$ for cows assigned a 45 -d dry period and $73(\mathrm{CI}=0.59$ to 0.87$)$ for those assigned a $30-\mathrm{d}$ dry period in group II. Protocol, herd, and herd $\times$ protocol interaction on the percentages of IMI cures were not statistically significant in either comparison group. Only 13 mammary quarters in 11 cows total had IMI by major pathogens (coagulase-positive staphylococci, environmental streptococci, and coliforms), and the cure rate was nearly $100 \%$. Major pathogen IMI were cured in all cows either assigned a 30- or 45-d dry period, and 5 of 7 IMI were cured in 60-d dry period cows. The majority of IMI were caused by the minor pathogens, coagulase-negative staphylococci $(\mathrm{n}=102)$ or Corynebacterium bovis $(\mathrm{n}=11)$. Cure rates by pathogen type did not differ between protocol within groups.

There was no significant prophylactic effect associated with any protocol (Tables 3 and 4). The percentage of new IMI at parturition ranged from 7 to $17 \%$ for all 4 herds. The average percentage of new IMI for both dry period comparisons ranged from 6 to $9 \%$. Total new IMI by pathogen type was not significantly affected by length of dry period for group I cows. Significantly ( $P$ $=0.04$ ) fewer major mastitis pathogen IMI were found in cows receiving the $45-\mathrm{d}$ dry period as compared with the 30-d dry period. However, the number of new IMI in 30 -d dry period cows was only $3 \%(4 / 118)$ as compared with none in the 45-d dry period.

The mean LSCC was not significantly affected by length of dry period (Table 5). Mature equivalent milk production was greater in group I cows assigned a 60-d dry period as opposed to those given a 30-d dry period $(11,942$ vs. $10,749 \mathrm{~kg} ; P<0.05)$. The GLM indicated a significant herd effect for this comparison group. Cows assigned a 45-d dry period did not produce more milk than cows with a 30-d dry period in group II. A herd $\times$ protocol interaction was not found to significantly affect the dependent variables milk production and LSCC as tested by GLM analyses for both groups I and II. The range in mean edema scores for cows given a 30-, 45-, or 60-d dry period was 2.3 to 2.8 (Table 5). Dry period length, herd, and herd by length of dry period had no significant effect on edema score. A set of milk 
Table 1. Effect of length of dry period on the proportion of infected mammary quarters that was cured of IMI during the dry period for cows given a 60 - or 30 -d dry period by herd

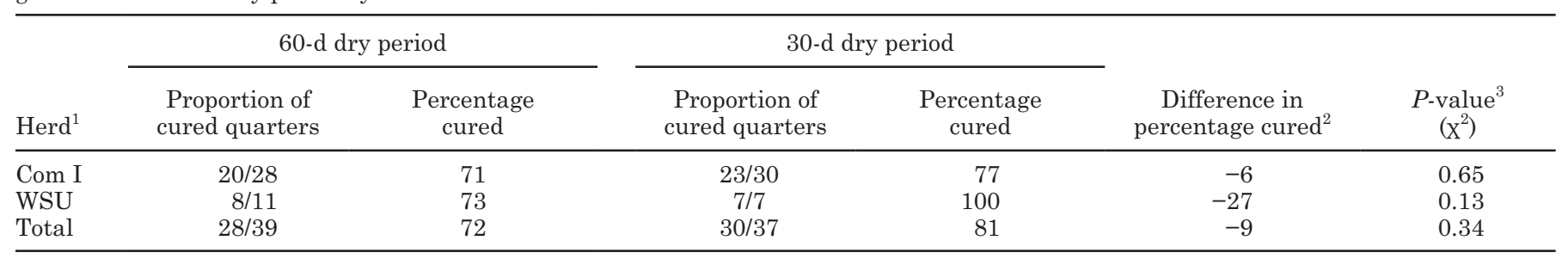

${ }^{1}$ Herds included in study: Com I = commercial herd 1; WSU = Washington State University.

${ }^{2}$ Percentage point difference $=$ difference in the percentage of mammary quarters that was cured in the long dry period compared with mammary quarters that were cured in the short dry period. The reference point is a value of zero. A positive percentage point indicated the proportion of mammary quarters that was cured was better in the long dry period than the long short period. A negative percentage point indicates that the proportion of mammary quarters that was cured was better in the short dry period than the long dry period.

${ }^{3} \mathrm{~A} P$-value $>0.05$ indicates that the difference in cure rates between long and short dry periods was not statistically significant.

samples was collected from 152 of 156 cows to screen for antibiotic residues. For cows $(n=72)$ given a $30-d$ dry period, 4 tested positive for residues at freshening, and one of these cows was positive at $7 \mathrm{~d}$ postpartum. For cows $(n=30)$ given a 45 -d dry period, 3 cows tested positive for residues at freshening, and none of those cows were positive at $7 \mathrm{~d}$ postpartum. For cows ( $\mathrm{n}=$ 50) given a 60-d dry period, 1 cow tested positive for residue at freshening and $7 \mathrm{~d}$ postpartum. Thus, only 8 cows $(5 \%)$ had positive antibiotic residues in the fresh cow sample, and their mean days dry was 41.5 with a range of 31 to $57 \mathrm{~d}$. Two cows (1 cow, 30-d dry period; 1 cow, 60-d dry period) had a positive residue $7 \mathrm{~d}$ postpartum with days dry at 33 and 48, respectively.

\section{DISCUSSION}

The principal thrust of this study was to determine if mammary gland health was affected negatively by shortening the dry period to $30 \mathrm{~d}$ as hypothesized. It was realized that antibiotic dry cow preparations are formulated to be long-acting and have prolonged milk withholding and meat withdrawal times of at least 28 d. A lactating cow antibiotic therapy was selected for administration to cows with $30-d$ dry periods in this study because of the unpredictability of length to parturition and to guard against excessive milk discard when shorter than expected dry periods occur. This study appears to be unique in that although mastitis status was an endpoint of previous investigations involving comparisons of dry period length, the type of dry cow therapy product used was not described in enough detail to determine if the product was formulated for lactating or dry cows (Gulay et al., 2003; Annen et al., 2004; Rastani et al., 2005; Kuhn et al., 2006a; Grusenmeyer et al., 2007; Pezeshki et al., 2007). The initial study was designed to set the long dry period length at $60 \mathrm{~d}$. However, 2 of the herd operators decided against lengthening the dry period from the 45-d assignment as practiced. Given expected efficacy of dry cow therapy $(75 \%)$ vs. lactating cow intramammary therapy for subclinical mastitis (23\%) cures, we determined that 21

Table 2. Effect of length of dry period on the proportion of infected mammary quarters that was cured of IMI during the dry period for cows given a 45- or 30-d dry period by herd

\begin{tabular}{|c|c|c|c|c|c|c|}
\hline Herd $^{1}$ & \multicolumn{2}{|c|}{ 45-d dry period } & \multicolumn{2}{|c|}{ 30-d dry period } & $\begin{array}{c}\text { Difference in } \\
\text { percentage cured }^{2}\end{array}$ & $\begin{array}{c}P \text {-value }{ }^{3} \\
\left(\mathrm{x}^{2}\right)\end{array}$ \\
\hline UI & $1 / 1$ & 100 & $5 / 5$ & 100 & 0 & -4 \\
\hline Total & $25 / 34$ & 74 & $27 / 37$ & 73 & 1 & 0.95 \\
\hline
\end{tabular}

${ }^{1}$ Herds included in study: Com II = commercial herd 2; UI = University of Idaho.

${ }^{2}$ Percentage point difference $=$ difference in the percentage of mammary quarters that was cured in the long dry period compared with mammary quarters that were cured in the short dry period. The reference point is a value of zero. A positive percentage point indicated the proportion of mammary quarters that was cured was better in the long dry period than the long short period. A negative percentage point indicates that the proportion of mammary quarters that was cured was better in the short dry period than the long dry period

${ }^{3} \mathrm{~A} P$-value $>0.05$ indicates that the difference in cure rates between long and short dry periods was not statistically significant.

${ }^{4}$ Undefined $=$ the relative risk ratio could not be computed when no infections were present in mammary quarters of either control or treated animals or when $100 \%$ of IMI was cured in all animals. 
Table 3. Prophylactic effect of length of dry period on new IMI during 60- vs. 30-d dry periods by herd

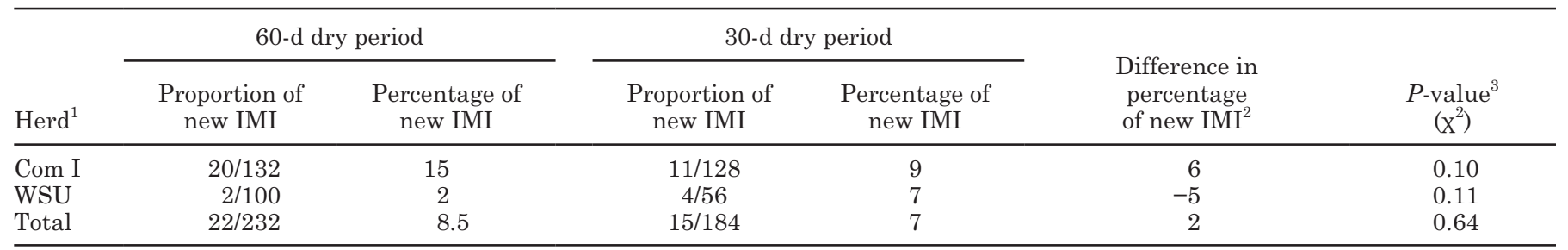

${ }^{1}$ Herds included in study: Com I = commercial herd 1; WSU = Washington State University.

${ }^{2}$ Percentage point difference $=$ difference in the percentage of mammary quarters that acquired a new IMI during the long dry period compared with mammary quarters that acquired a new IMI during the short dry period. The reference point is a value of zero. A positive percentage point indicates that the proportion of mammary quarters that acquired a new IMI was lower in the short dry period than the long dry period. A negative percentage point indicates that the proportion of mammary quarters that acquired a new IMI was lower in the long dry period than the short dry period.

${ }^{3} \mathrm{~A} P$-value $>0.05$ indicates that the rate of a new IMI between long and short dry cow treatments was not significantly different.

cows per treatment were required to obtain sufficient power of the test. We met or exceeded the minimum number of experimental units assigned to each treatment comparison within group.

Results of this study indicate that upon freshening, mammary gland health of cows given a 30-d dry period and administered a commercial lactating cow intramammary antibiotic product did not differ from that of cows given a commercial dry cow intramammary product with the same antibiotic for their 45- or 60-d dry periods. It is not clear if this was an effect of dry period length, type of antibiotic formulation used, or their interaction, because dry period length assignment and dry cow intramammary therapy were confounded. No significant differences in percentage of cures of existing IMI, nor prevention of new IMI, between protocols were found. Moreover, LSCC did not differ between dry period groups. Thus, data from this study would not support acceptance of the hypothesis. Results herein are consistent with those from studies in which milk SCC was the only measure of mammary gland health. Gulay et al. (2003) and Annen et al. (2004) reported that cows given theoretical $30-d$ vs. $60-d$ dry periods had insignificant differences in their milk SCC, similar to that found by Grusenmeyer et al. (2007), in which the comparison was made between cows with 40- vs. 60-d dry periods. Rastani et al. (2005) gave cows theoretical dry periods of 56 and $28 \mathrm{~d}$ and reported no difference in postpartum milk SCC scores. Last, Pezeshki et al. (2007) compared postpartum SCC for cows with theoretical 56-, 42-, and 35-d dry periods. They reported that, for combined data across all parities, cell counts were not affected by length of dry period. Contrary to the aforementioned experimental intervention studies in which cows were assigned to theoretical dry period lengths, Kuhn et al. (2006b) examined DHIA records and reported that SCC in the subsequent lactation increase with decreasing dry period length when a $60-\mathrm{d}$ dry period was used as the reference point. Thus, data from this study indicate that IMI at calving did not change when dry period length decreased and a commercial lactating intramammary antibiotic treatment was instilled at dry-off. The similar LSCC in subsequent lactations reflect the lack of difference in IMI in agreement with almost all other studies.

The majority of IMI at parturition were caused by the minor pathogens, CNS, and C. bovis. Cure rates by herd ranged from 69 to $100 \%$, with an overall average

Table 4. Prophylactic effect of length of dry period on new IMI during 45- vs. 30-d dry periods by herd

\begin{tabular}{|c|c|c|c|c|c|c|}
\hline Herd $^{1}$ & \multicolumn{2}{|c|}{ 45-d dry period } & \multicolumn{2}{|c|}{ 30-d dry period } & $\begin{array}{l}\text { Difference in } \\
\text { percentage } \\
\text { of new } \text { IMI }^{2}\end{array}$ & $\begin{array}{c}P \text {-value }{ }^{3} \\
\left(\mathrm{x}^{2}\right)\end{array}$ \\
\hline UI & $2 / 12$ & 17 & $4 / 23$ & 17 & 0 & 0.96 \\
\hline Total & $8 / 120$ & 7 & $7 / 118$ & 6 & 1 & 0.82 \\
\hline
\end{tabular}

${ }^{1}$ Herds included in study: Com II = commercial herd 2; UI = University of Idaho.

${ }^{2}$ Percentage point difference $=$ difference in the percentage of mammary quarters that acquired a new IMI during the long dry period compared with mammary quarters that acquired a new IMI during the short dry period. The reference point is a value of zero. A positive percentage point indicates that the proportion of mammary quarters that acquired a new IMI was lower in the short dry period than the long dry period. A negative percentage point indicates that the proportion of mammary quarters that acquired a new IMI was lower in the long dry period than the short dry period.

${ }^{3} \mathrm{~A} P$-value $>0.05$ indicates that the rate of a new IMI between long and short dry cow treatments was not significantly different. 
Table 5. Mean $( \pm \mathrm{SD})$ milk production, milk linear SCC, and edema scores for cows in the long and short dry periods

\begin{tabular}{|c|c|c|c|c|}
\hline Treatment $^{1}$ & Group $^{2}$ & $\begin{array}{l}\text { Production }^{3} \\
\text { (305-d mature } \\
\text { equivalent) }\end{array}$ & $\begin{array}{l}\text { Linear } \\
\text { SCC }^{4}\end{array}$ & $\begin{array}{l}\text { Edema } \\
\text { score }\end{array}$ \\
\hline 30-d dry period & I & $10,749(2,059)$ & $2.3(2.1)$ & $2.4(1.1)$ \\
\hline 30-d dry period & II & $11,147(1,239)$ & $2.3(1.6)$ & $2.3(0.7)$ \\
\hline 45-d dry period & II & $11,104(1,635)$ & $1.8(1.6)$ & $2.6(0.6)$ \\
\hline
\end{tabular}

${ }^{1}$ Long $(45$ and $60 \mathrm{~d})$ treatment received dry cow intramammary antibiotic therapy at dry-off. Short (30 d) treatment received lactating cow intramammary antibiotic therapy at dry-off.

${ }^{2}$ Group I included cows in herds given either a 30- or 60-d dry period. Group II included cows in herds given either a 30- or 45-d dry period.

${ }^{3}$ The projected $305 \mathrm{~d}$ mature equivalent milk production $(\mathrm{kg})$ record was used from the monthly DHIA test that was most proximate to $200 \mathrm{~d}$ in milk. Only cows in lactation greater than $170 \mathrm{~d}$ were included. Milk production records of cows given a 30-vs. a 60-d dry period, comparison I, were significantly different $(P<0.05)$.

${ }^{4}$ Linear SCC scores, within comparison groups, were not different.

of $75 \%(110 / 147)$. Overall, the new IMI by theoretical dry period length ranged from 6 to $9 \%$. These values are very similar to those reported by Harmon et al. (1986) for cows treated with cephapirin in a herd in which minor pathogens caused more than $90 \%$ of all IMI at dry-off.

Use of lactating cow therapy for cows with a short dry period did not result in prolonged presence of residues in milk postpartum. Residues could only be detected from the milk of 8 cows at freshening, and numbers were equally divided between long and short dry period groups. Residues could only be detected in milk of 2 cows at $7 \mathrm{~d}$ postpartum, split between long and short dry period groups. Residues were not detected in milk samples collected $14 \mathrm{~d}$ postpartum. Yet, the appearance of residues in milk in any postpartum samples when milk is normally salable argues strongly for monitoring of milk for residues during the postpartum period.

Mature equivalent milk production was significantly lower in cows given a 30-d, as compared with those with a $60-d$, dry period. No significant difference in mature equivalent 305-d lactations was noted when 30-vs. 45-d dry period cows were compared. Results of previous studies on the optimum length of the dry period are mixed. It can be argued that milk production gained from the greater length of the previous lactation should be added to the production of the lactation that follows the shorter dry period (Bachman and Schairer, 2003; Kuhn et al., 2006a). With that credit, total lifetime milk production might favor those cows with shorter dry periods. There is a need to evaluate the effect of shorter dry periods on lifetime production (Kuhn et al., 2006a). Based on experience, the first dairy producer to enroll in the study was concerned with the incidence of edema associated with shorter dry period length. Thus, edema scoring was added to the study, and it was determined that edema scores on average were lower, but not significantly, for cows with shorter dry periods.
In conclusion, the data reported in this study demonstrate that mammary gland health, as measured by prevalence of infections at parturition and milk SCC scores during the postpartum period, does not necessarily suffer with shortened dry periods. Thus, the expected udder health after the use of a lactating cow commercial antibiotic intramammary therapy for cows enrolled to have 30-d dry periods was equivalent to cows with a 60-d dry period that received a standard dry cow therapy. Antibiotic residues in milk $7 \mathrm{~d}$ postpartum were rare and no greater among the group of cows given a 30-d dry period than those with a longer dry period. Milk production for cows given a theoretical 45-d dry period was equivalent to those with a 30-d appointed period during the subsequent lactation. Production differed from those cows given a 60- $d$ dry period as opposed to those with a 30 -d period in which yields were significantly greater for the 60-d group. Dairy managers enrolling their cows in 30-d dry periods must be aware of the potential gain in productive days in the previous lactation before the shorter dry period. This increase in more productive days might offset the decreased yield in the subsequent lactation with a shorter dry period as suggested by Bachman and Schairer (2003). Importantly, the findings of this study indicate that there should be no untoward udder health events associated with shorter dry periods and no greater risk of antibiotic residues in milk postpartum in cows with shortened dry periods when cows are treated with an intramammary antibiotic product formulated for lactating cows.

\section{REFERENCES}

Annen, E. L., R. J. Collier, M. A. McGuire, J. L. Vicini, J. M. Ballam, and M. J. Lormore. 2004. Effect of modified dry period lengths and bovine somatotropin on yield and composition of milk from dairy cows. J. Dairy Sci. 87:3746-3761. 
Bachman, K. C., and M. L. Schairer. 2003. Invited review: Bovine studies on optimal lengths of dry periods. J. Dairy Sci. 86:30273037.

Dix Arnold, P. T., and R. B. Becker. 1936. Influence of preceding dry period and of mineral supplementation on lactation. J. Dairy Sci. 19:257-266.

Dodd, F. H., D. R. Westgarth, F. K. Neave, and R. G. Kingwell. 1969. Mastitis-The strategy of control. J. Dairy Sci. 52:689-695.

Erskine, R. J., S. Wagner, and F. J. DeGraves. 2003. Mastitis therapy and pharmacology. Vet. Clin. North Am. Food Anim. Pract. 19:109-138.

Grusenmeyer, D. J., C. M. Ryan, R. W. Everett, D. M. Galton, and T. R. Overton. 2007. Effects of shortening the dry period from 60 to $40 \mathrm{~d}$ on milk yield and composition during the subsequent lactation. J. Dairy Sci. 85(Suppl. 1):606. (Abstr.)

Gulay, M. S., M. J. Hayen, K. C. Bachman, T. Belloso, M. Liboni, and H. H. Head. 2003. Milk production and feed intake of Holstein cows given short (30-d) or normal (60-d) dry period. J. Dairy Sci. 86:2030-2038

Gulay, M. S., M. J. Hayen, H. H. Head, C. J. Wilcox, and K. C. Bachman. 2005. Milk production from Holstein half udders after concurrent thirty- and seventy-day dry periods. J. Dairy Sci. 88:3953-3962.

Harmon, R. J., W. L. Crist, R. W. Hemken, and B. E. Langlois. 1986. Prevalence of minor udder pathogens after intramammary dry treatment. J. Dairy Sci. 69:843-849.

Hogan, J. S., R. N. Gonzalez, R. J. Harmon, S. C. Nickerson, S. P. Oliver, J. W. Pankey, and K. L. Smith. 1999. Laboratory Handbook on Bovine Mastitis. National Mastitis Council Inc., Madison, WI.
Hurley, W. L. 1989. Symposium: Mammary gland function during involution and the declining phase of lactation. J. Dairy Sci. 72:1637-1646.

Kuhn, M. T., J. L. Hutchinson, and H. D. Norman. 2006a. Dry period length to maximize production across adjacent lactations and lifetime production. J. Dairy Sci. 89:1713-1722.

Kuhn, M. T., J. L. Hutchison, and H. D. Norman. 2006b. Effects of length of dry period on yields of milk fat and protein, fertility and milk somatic cell score in the subsequent lactation of dairy cows. J. Dairy Res. 73:154-162.

Kuhn, M. T., J. L. Hutchinson, and H. D. Norman. 2007. Dry period length in US Jerseys: Characterization and effects on performance. J. Dairy Sci. 90:2069-2081.

Nestor, K. E., R. W. Hemken, and R. J. Harmon. 1988. Influence of sodium chloride and potassium bicarbonate on udder edema and selected blood parameters. J. Dairy Sci. 71:366-372.

Pezeshki, A., J. Mehrzad, G. R. Ghorbani, H. R. Rahmani, R. J. Collier, and C. Burvenich. 2007. Effects of short dry periods on performance and metabolic status in Holstein dairy cows. J. Dairy Sci. 90:5531-5541.

Rastani, R. R., R. R. Grummer, S. J. Bertics, A. Gümen, M. C. Wiltbank, D. G. Mashek, and M. C. Schwab. 2005. Reducing dry period length to simplify feeding transition cows: Milk production, energy balance, and metabolic profiles. J. Dairy Sci. 88:1004-1014.

Timms, L. L., and L. H. Schultz. 1984. Mastitis therapy for cows with elevated somatic cell counts or clinical mastitis. J. Dairy Sci. 67:367-371. 